\title{
Further Observations on Kell Blood Groups in Families Ascertained via a Mongol Propositus
}

\author{
D. A. PRICE EVANS, P. J. J. WREN, W. T. A. DONOHOE, M. F. BULLEN, \\ MARION LEWIS, HIROKO KAITA, BRUCE CHOWN, and IRENE UCHIDA
}

\begin{abstract}
From Nuffield Unit of Medical Genetics, Department of Medicine, University of Liverpool, Liverpool, U.K.; and $R h$ Laboratory and Department of Paediatrics, University of Manitoba, Winnipeg, Canada
\end{abstract}

Genes located on the unpaired portion of the human $\mathrm{X}$ chromosome can readily be recognized, but as far as the autosomes are concerned it is not known upon which autosome any human gene is located.

The common variety of mongolism is characterized by 21-trisomy, and offers a possible approach to the localization of human autosomal genes. The model on which this approach is based was first formulated by Bateman (1960) and later developed by Shaw and Gershowitz (1962), Penrose (1963), Kaplan et al. (1964), and Goodman (1965). The essential experimental finding would be a reduced incidence of a recessive phenotype or homozygous genotype in the 21 trisomics as compared with nontrisomics, which would indicate that the genes controlling the polymorphism involved were located on chromosome 21. Results testing the ABO blood group system were published by Shaw and Gershowitz (1962, 1963), Chown and Lewis (1963), Kaplan et al. (1964), and Goodman and Thomas (1966). From these results it seems very unlikely that the $\mathrm{ABO}$ locus is on autosome 21.

Evans et al. (1966) analysed data collected in Liverpool, in Buffalo, New York, U.S.A., and from a London series in the paper of Lang-Brown, Lawler, and Penrose (1952/53). Data on nine blood group systems and salivary $\mathrm{ABH}$ secretion were analysed. The only significant association between blood group phenotype and mongolism was found in the case of Kell where a significant excess of Kell-positive mongols was found. This finding raised the possibility that the Kell locus might be on chromosome 21 .

Objections to concluding that the human Kell locus was on chromosome 21 were discussed. Among others it was pointed out that since a number of polymorphisms had been investigated the statisti-

Received May 6, 1968. cal significance level of a result on a single system would have to be weighted appropriately, and that the ideal confirmatory procedure would be to analyse statistically only the Kell blood grouping results from an entirely new population of mongols and their sibs.

The present paper presents the results of such a confirmatory procedure.

\section{Materials and Methods}

The studies were carried out independently in Liverpool and Winnipeg. Where the methods were different this is stated.

Subjects. Mongol propositi were located in the following ways:

(i) In England from the general practice list of one of us (P.J.J.W.) and his partners at Chorley; from investigations at Lisieux Hall Mental Institution, Whittle-leWoods, near Chorley, Lancashire, and from lists supplied by the Medical Officers of Health of Chorley, Birkenhead, and S.W. Lancashire, all of whom have responsibilities for providing educational facilities for mentally backward children.

(ii) In Manitoba from investigations at the Manitoba School for Retardates; or through a list supplied by the school; or through reference by private physicians or the Public Health Service. An attempt was made to see, examine, and test every mongol in Manitoba (population $1,000,000)$.

Diagnosis of Mongolism. All Manitoba mongols were seen by one of us (I.U.) as part of her study of mongolism. The diagnosis was made on clinical grounds and was confirmed by dermatoglyphs and by karyotypes. Only trisomics and their relatives, and only families in which at least the mongol and both parents had been blood grouped, have been analysed in this paper.

The diagnosis of the British mongols was a purely clinical one. Mongol propositi were not accepted unless they had typical physiognomic features. Karyotyping facilities were not available in Liverpool for the large number of subjects involved. 
TABLE I

MANITOBA FAMILIES ASCERTAINED VIA A TRISOMIC PROPOSITUS

\begin{tabular}{|c|c|c|c|c|c|c|c|}
\hline \multirow[t]{2}{*}{ Kell Typing } & \multirow[t]{2}{*}{$\begin{array}{c}\text { All Members of Families } \\
\mathbf{K}-\mathbf{k}+\mathbf{K} \mathbf{p}(\mathbf{a}-\mathbf{b}+)\end{array}$} & \multicolumn{4}{|c|}{$\begin{array}{c}\text { Families which have } \\
\text { members not } \\
\mathbf{K}-\mathbf{k}+\mathbf{K p}(\mathbf{a}-\mathbf{b}+)\end{array}$} & \multirow[t]{2}{*}{ Total } & \multirow[t]{2}{*}{$\begin{array}{l}\% \text { Kell } \\
\text { Positive }\end{array}$} \\
\hline & & $\mathbf{k}^{\mathbf{b}} \mathbf{k}^{\mathbf{b}}$ & $\mathbf{k}^{\mathbf{a}} \mathbf{k}^{\mathbf{b}}$ & $\mathbf{K k}^{\mathbf{b}}$ & KK & & \\
\hline $\begin{array}{l}\text { Male mongols } \\
\text { Female mongols } \\
\text { Fathers of mongols } \\
\text { Mothers of mongols } \\
\text { Brothers of mongols } \\
\text { Sisters of mongols }\end{array}$ & $\begin{array}{l}112 \\
110 \\
215 \\
215 \\
289 \\
258\end{array}$ & $\begin{array}{l}10 \\
14 \\
16 \\
25 \\
22 \\
32\end{array}$ & $\begin{array}{l}1 \\
2 \\
2 \\
5 \\
6 \\
1\end{array}$ & $\begin{array}{r}8 \\
7 \\
24 \\
12 \\
30 \\
20\end{array}$ & $\begin{array}{l}\text { Nil } \\
\text { Nil } \\
\text { Nil } \\
\text { Nil } \\
\text { Nil } \\
1\end{array}$ & $\begin{array}{l}131 \\
133 \\
257 \\
257 \\
347 \\
312\end{array}$ & 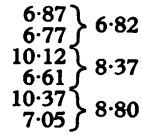 \\
\hline
\end{tabular}

Note: For the purpose of this analysis $\mathrm{k}^{\mathrm{a}}$ is taken as equivalent to $\mathrm{K}$. There were three sets of monozygous female mongols; they were each counted as one. There were also two non-mongol sibs whose sex was not recorded; they have been omitted.

Relatives of Mongol Propositi. All available sibs and the parents were ascertained for the Manitoba mongols.

In the British mongols a non-mongol sib was ascertained along with each mongol propositus. Mongols without an available non-mongol sib were not investigated. Wherever possible the non-mongol sib nearest in age to the mongol propositus and the parents of the propositi were examined.

Later in the study all available non-mongol sibs were ascertained in families where one or other of the parents of Buitish mongols had been shown to possess the Kell antigen.

Control Families. In England a control nonmongol matched propositus was selected from the general practice list at Chorley already indicated. Each mongol propositus in the Chorley series was matched by a control non-mongol propositus of the same sex, age, socio-economic status, location of domicile, and cultural background. A non-mongol sib, and wherever possible, the parents of the control non-mongol matched propositus were also investigated in the same manner as for mongol propositi.

Blood Samples. The Manitoba samples were collected from 1962 to November 1967. All were venous samples. They were collected in mental institutions, in hospitals, in the genetics laboratory, and in the homes of propositi or their relatives, and were delivered as soon as convenient to the $\mathrm{Rh}$ Laboratory. All were typed for the ABO, MNSs, Rh, P, Kell, Lutheran, Lewis, Duffy, Kidd, and $\mathrm{Xg}$ systems, many for the $\mathrm{Bu}^{\mathrm{a}}$-Sm system, and for a variety of high and low frequency antigens. The facts so obtained were used to check paternity, but only the Kell data were statistically analysed in the present study.

The British blood samples were taken by venepuncture from almost all subjects. Blood from a few uncooperative mongol subjects was obtained by ear-prick. The blood samples taken at Chorley were sent by overnight letter post to the blood grouping laboratory in Liverpool and the samples taken in Birkenhead and South West Lancashire were taken there immediately. All British blood samples were typed for their Kell blood group with
anti-K antiserum within 36 hours of collection. Typing with anti-k antiserum was not regularly performed.

Antisera. The sera of the Kell system used in the Manitoba study and the methods by which they were used were the same as described by Chown et al. (1963), save that latterly the anti-Kp $\mathrm{p}^{\mathrm{b}}$ has been used by the indirect Coombs technique. All samples were tested with anti-K, $-k,-K p^{a}$, and $-K p^{b}$.

The British blood samples werestested with orthoimmune specific anti-Kell (and active by indirect Coombs test only. No other wayd srotup systems were tested.

Method of C. A. B. Smith for Evaluating Associations within Families. This method utilizes segregating sibships, and is fully explained in the paper of Clarke et al. (1956) where it was first used to test the association between blood group $\mathrm{O}$ and duodenal ulcer within sibships.

\section{Results}

Manitoba families are analysed in Table $I$, and it will be seen that the frequency of the Kell antigen is not higher in the trisomics than in their parents or sibs.

Data on British families of phenotypically characteristic mongols and on families of controls are presented in Tables II and III, respectively.

Table IV shows data from Chorley families. The frequency of Kell-positive is not higher in the mongols than in their parents or sibs. The frequency of Kell-positive is not higher in mongols than in control non-mongol matched propositi. It is also clear than the matings which give rise to mongols do not have a different incidence of Kellpositive from those which have produced control non-mongol propositi.

The frequency of Kell positive in the parents of Manitoba trisomics and in the parents of the British phenotypically characteristic mongols is seen to be similar in Table V. 
TABLE II

KELL TYPING INFORMATION ON BRITISH FAMILIES ASCERTAINED BY MEANS OF PHENOTYPICALLY CHARACTERISTIC MONGOL PROPOSITUS

\begin{tabular}{|c|c|c|c|c|c|}
\hline $\begin{array}{l}\text { Area from Which } \\
\text { Family Derived }\end{array}$ & $\underset{\text { Member }}{\text { Family }}$ & Sex & $\begin{array}{l}\text { No. } \\
\text { Tested }\end{array}$ & $\begin{array}{c}\text { Kell } \\
\text { Positive }\end{array}$ & $\begin{array}{c}\text { Kell } \\
\text { Negative }\end{array}$ \\
\hline Chorley & $\begin{array}{c}\text { Mongol } \\
\text { Sib } \\
\text { Father } \\
\text { Mother }\end{array}$ & $\begin{array}{l}M \\
F \\
M \\
F \\
M \\
F\end{array}$ & $\begin{array}{l}42 \\
28 \\
33 \\
37 \\
67 \\
71\end{array}$ & $\begin{array}{l}2 \\
1 \\
0 \\
6 \\
6 \\
6\end{array}$ & $\begin{array}{l}40 \\
27 \\
33 \\
31 \\
61 \\
65\end{array}$ \\
\hline Birkenhead & $\begin{array}{c}\text { Mongol } \\
\text { Sib } \\
\text { Father } \\
\text { Mother }\end{array}$ & $\begin{array}{l}M \\
F \\
M \\
F \\
M \\
F\end{array}$ & $\begin{array}{r}6 \\
11 \\
10 \\
7 \\
17 \\
17\end{array}$ & $\begin{array}{l}1 \\
1 \\
0 \\
0 \\
1 \\
3\end{array}$ & $\begin{array}{r}5 \\
10 \\
10 \\
7 \\
16 \\
14\end{array}$ \\
\hline SW Lancs. & $\begin{array}{c}\text { Mongol } \\
\text { Sib } \\
\text { Father } \\
\text { Mother }\end{array}$ & $\begin{array}{l}M \\
F \\
M \\
F \\
M \\
F\end{array}$ & $\begin{array}{l}15 \\
18 \\
19 \\
13 \\
27 \\
31\end{array}$ & $\begin{array}{l}0 \\
2 \\
1 \\
2 \\
3 \\
2\end{array}$ & $\begin{array}{l}15 \\
16 \\
18 \\
11 \\
24 \\
29\end{array}$ \\
\hline
\end{tabular}

TABLE III

KELL TYPING INFORMATION ON CONTROL FAMILIES DERIVED FROM CHORLEY

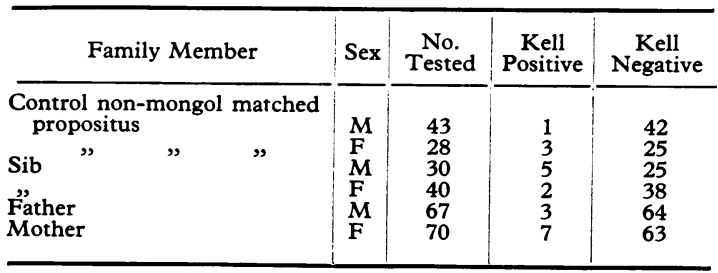

An analysis of the sibships segregating for the presence of the Kell antigen is shown in Table VI. There is no significant difference between the observed number of Kell positive mongols and the number expected by chance. (Appendices giving the results in full are available on application to one of us (D.A.P.E.)).

\section{TABLE IV}

INCIDENCE OF KELL POSITIVE IN CHORLEY FAMILIES

\begin{tabular}{|c|c|c|c|c|}
\hline \multirow[t]{2}{*}{$\underset{\text { Member }}{\text { Family }}$} & \multicolumn{2}{|c|}{$\begin{array}{c}\text { Families Ascertained } \\
\text { by Means of } \\
\text { Phenotypically } \\
\text { Characteristic Mongol } \\
\text { Propositus }\end{array}$} & \multicolumn{2}{|c|}{$\begin{array}{l}\text { Families Ascertained } \\
\text { by Means of } \\
\text { Control Non-mongol } \\
\text { Matched Propositus }\end{array}$} \\
\hline & $\begin{array}{l}\text { No. } \\
\text { Tested }\end{array}$ & Kell Positive & $\begin{array}{l}\text { No. } \\
\text { Tested }\end{array}$ & Kell Positive \\
\hline $\begin{array}{l}\text { Propositus } \\
\text { Sib } \\
\text { Parents }\end{array}$ & $\begin{array}{r}70 \\
70 \\
138\end{array}$ & $\begin{array}{l}4 \cdot 29 \\
8 \cdot 57 \\
8 \cdot 69\end{array}$ & $\begin{array}{r}71 \\
70 \\
137\end{array}$ & $\begin{array}{r}5 \cdot 63 \\
10 \cdot 00 \\
7 \cdot 30\end{array}$ \\
\hline
\end{tabular}

\section{Conclusion}

The data contained in the present report lend no $\stackrel{\mathbb{D}}{\overparen{D}}$ support to the tentative suggestion made earlier by $\stackrel{\mathbb{P}}{=}$ Evans et al. (1966) that the Kell locus may be on chromosome 21.

\section{Summary}

A previously reported examination of multiple $\overparen{\otimes}$ blood group systems in mongol propositi and a control non-mongol sib of each propositus yielded prima facie evidence that genes controlling the Kell blood $\vec{\circ}$ group might be located on autosome 21. This $\overrightarrow{\vec{\omega}}$ suggestion has now been re-examined by the investi- $\stackrel{\sigma}{\omega}$ gation of two entirely new populations of mongol propositi and their relatives. Statistical analyses of these results are presented and give no support to the original suggestion.

The authors in Liverpool acknowledge the following 음 help.

The United Liverpool Hospitals Research Committee (Chairman, Lord Cohen of Birkenhead) and the Nuffield $\mathbb{D}$ Foundation (via Professor C. A. Clarke) for generous financial support; Professor P. M. Sheppard, F.R.S., for help and advice; Miss D. Townsend and Miss H. Millington for assistance with blood grouping; Dr. J. Walker and Dr. J. Webster, the Lancashire County $\overrightarrow{0}$ Council Medical Officers of Health, Divisions 4 and 8 Dr. J. S. G. Burnet, Medical Officer of Health, Preston County Borough; Dr. J. G. Hailwood, Medical Offices. of Health for Crosby, Lancashire; Dr. J. W. Lobbain Medical Officer of Health for Birkenhead, Cheshire; an a Dr. J. W. Maybury and Dr. J. B. Wright (partners of Dr. P. J. J. Wren) for allowing us access to their patients.

The authors in Winnipeg acknowledge U.S. N.I.H. Grant 5 RO1HD 00527-07; and National Foundation Grant C.R.M.S. 194.

\section{REFERENCE;}

Bateman, A. J. (1960). Blood-group distribution to be expected in persons trisomic for the ABO gene. Lancet, 1, 1293.

Chown, B., and Lewis, M. (1963). ABO blood groups of mongols. Canad. med. Ass. F., 89, 906.

,-- Kaita, H., and Philipps, S. (1963). Some blood group frequencies in a Caucasian population. Vox Sang. (Basel), 8, 378.

TABLE V

COMPARISON OF KELL POSITIVE AND KELL NEGATIVE IN PARENTS OF TRISOMIC MANITOBA MONGOLS WITH SAME REACTIONS IN PARENTS OF BRITISH PHENOTYPICALLY CHARACTERISTIC MONGOLS

\begin{tabular}{c|c|c|c}
\hline & $\begin{array}{c}\text { Kell } \\
\text { Positive }\end{array}$ & $\begin{array}{c}\text { Kell } \\
\text { Negative }\end{array}$ & Total \\
\cline { 1 - 2 } $\begin{array}{c}\text { Manitoba parents } \\
\text { British parents }\end{array}$ & 43 & 471 & 514 \\
\hline Total & 21 & 209 & 230 \\
\hline
\end{tabular}

Note: For purpose of this analysis $\mathbf{k}^{\mathbf{a}}$ is taken as equivalent to $\mathbf{K}$.

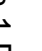




\section{TABLE VI}

ALL FAMILIES ASCERTAINED BY MEANS OF MONGOL PROPOSITUS AND SEGREGATING FOR PRESENCE OF KELL ANTIGEN

[ $\mathrm{K}$ here includes the antigen $\mathrm{K}$ and the antigen $\mathrm{k}^{\mathrm{a}}$ ]

\begin{tabular}{|c|c|c|c|c|c|c|c|}
\hline Family I & & $\begin{array}{c}\text { x } \\
\text { No. of } \\
\text { Mongols } \\
\text { with Kell } \\
\text { Antigen } \\
\text { in } \\
\text { Family }\end{array}$ & $\begin{array}{c}\mathrm{N}_{\mathrm{K}} \\
\text { No. of } \\
\text { Offspring } \\
\text { with Kell } \\
\text { Antigen } \\
\text { in } \\
\text { Family }\end{array}$ & $\begin{array}{c}\text { N } \\
\text { Total } \\
\text { No. of } \\
\text { Offspring } \\
\text { in } \\
\text { Family }\end{array}$ & $\begin{array}{c}\mathrm{N}_{\mathrm{L}} \\
\text { No. of } \\
\text { Offspring } \\
\text { without } \\
\text { Kell } \\
\text { Antigen } \\
\text { in } \\
\text { Family }\end{array}$ & $\begin{array}{c}\frac{\mathrm{N}_{\mathrm{K}}}{\mathrm{N}} \\
\text { Expected } \\
\text { No. of } \\
\text { Mongols } \\
\text { with Kell } \\
\text { Antigen } \\
\text { in } \\
\text { Family }\end{array}$ & $\begin{array}{c}\frac{\mathrm{N}_{\mathrm{K}} \mathrm{N}_{\mathrm{L}}}{\mathrm{N}^{2}} \\
\text { Variance }\end{array}$ \\
\hline Manitoba. & $\begin{array}{r}209 \\
161 \\
93 \\
227 \\
174 \\
2 \\
256 \\
187 \\
207 \\
240 \\
206 \\
92 \\
117 \\
180 \\
203 \\
72 \\
13 \\
193 \\
94 \\
122 \\
262 \\
195 \\
21 \\
49 \\
127\end{array}$ & $\begin{array}{l}0 \\
0 \\
1 \\
1 \\
1 \\
1 \\
1 \\
0 \\
1 \\
0 \\
0 \\
1 \\
1 \\
0 \\
0 \\
1 \\
0 \\
0 \\
0 \\
0 \\
0 \\
1 \\
0 \\
1 \\
1\end{array}$ & $\begin{array}{l}2 \\
3 \\
4 \\
2 \\
2 \\
2 \\
4 \\
3 \\
3 \\
1 \\
1 \\
6 \\
1 \\
1 \\
2 \\
2 \\
2 \\
3 \\
1 \\
1 \\
3 \\
7 \\
1 \\
3 \\
2\end{array}$ & $\begin{array}{l}7 \\
5 \\
6 \\
3 \\
4 \\
3 \\
5 \\
5 \\
5 \\
3 \\
2 \\
9 \\
4 \\
3 \\
3 \\
3 \\
4 \\
7 \\
3 \\
5 \\
6 \\
8 \\
6 \\
7 \\
4\end{array}$ & $\begin{array}{l}5 \\
2 \\
2 \\
1 \\
2 \\
1 \\
1 \\
2 \\
2 \\
2 \\
1 \\
3 \\
3 \\
2 \\
1 \\
1 \\
2 \\
4 \\
2 \\
4 \\
3 \\
1 \\
5 \\
4 \\
2\end{array}$ & 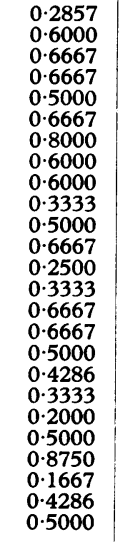 & $\begin{array}{l}0 \cdot 2041 \\
0 \cdot 2400 \\
0 \cdot 2222 \\
0 \cdot 2222 \\
0 \cdot 2500 \\
0 \cdot 2222 \\
0 \cdot 1600 \\
0 \cdot 2400 \\
0 \cdot 2400 \\
0 \cdot 2222 \\
0 \cdot 2500 \\
0 \cdot 2222 \\
0 \cdot 1875 \\
0 \cdot 2222 \\
0 \cdot 2222 \\
0 \cdot 2222 \\
0 \cdot 2500 \\
0 \cdot 2449 \\
0 \cdot 2222 \\
0 \cdot 1600 \\
0 \cdot 2500 \\
0 \cdot 1094 \\
0 \cdot 1389 \\
0 \cdot 2449 \\
0 \cdot 2500\end{array}$ \\
\hline Chorley & $\begin{array}{l}24 \\
25 \\
36 \\
37 \\
48 \\
61\end{array}$ & $\begin{array}{l}0 \\
0 \\
0 \\
1 \\
0 \\
0\end{array}$ & $\begin{array}{l}1 \\
2 \\
1 \\
1 \\
1 \\
1\end{array}$ & $\begin{array}{l}3 \\
3 \\
2 \\
2 \\
2 \\
2\end{array}$ & $\begin{array}{l}2 \\
1 \\
1 \\
1 \\
1 \\
1\end{array}$ & $\begin{array}{l}0.3333 \\
0.6667 \\
0.5000 \\
0.5000 \\
0.5000 \\
0.5000\end{array}$ & $\begin{array}{l}0.2222 \\
0.2222 \\
0.2500 \\
0.2500 \\
0.2500 \\
0.2500\end{array}$ \\
\hline Birkenhead & $\begin{array}{r}8 \\
12 \\
13\end{array}$ & $\begin{array}{l}1 \\
1 \\
0\end{array}$ & $\begin{array}{l}1 \\
4 \\
1\end{array}$ & $\begin{array}{l}2 \\
6 \\
4\end{array}$ & $\begin{array}{l}1 \\
2 \\
3\end{array}$ & $\begin{array}{l}0.5000 \\
0.6667 \\
0.2500\end{array}$ & $\begin{array}{l}0.2500 \\
0.2222 \\
0.1875\end{array}$ \\
\hline SW Lancs. & 33 & 0 & 1 & 2 & 1 & 0.5000 & $0 \cdot 2500$ \\
\hline Totals & & 15 & & & & $17 \cdot 6514$ & $7 \cdot 7736$ \\
\hline
\end{tabular}

Clarke, C. A., Edwards, J. W., Haddock, D. R. W., Howel-Evans, A. W., McConnell, R. B., and Sheppard, P. M. (1956). ABO blood groups and secretor character in duodenal ulcer. Population and sibship studies. Brit. med.f., 2, 725.

Evans, D. A. P., Donohoe, W. T. A., Bannerman, R. M., Mohn, J. F., and Lambert, R. M. (1966). Blood-group gene localization through a study of mongolism. Ann. hum. Genet., 30, 49.

Goodman, H. O. (1965). Phenotypic shifts in trisomy. Amer. f. hum. Genet., 17, 111.

$\longrightarrow$, and Thomas, J. J. (1966). ABO frequencies in mongolism. Ann. hum. Genet., 30, 43.
Kaplan, S., Li, C. C., Wald, N., and Borges, W. (1964). ABO frequencies in mongols. ibid., $27,405$.

Lang-Brown, H., Lawler, S. D., and Penrose, L. S. (1952/53). The blood typing of cases of mongolism, their parents and sibs. Ann. Eugen. (Lond.), 17, 307.

Penrose, L. S. (1963). Measurements of likeness in relatives of trisomics. Ann. hum. Genet., 27, 183.

Shaw, M. W., and Gershowitz, H. (1962). A search for autosomal linkage in a trisomic population. Blood group frequencies in mongols. Amer. F. hum. Genet., 14, 317.

15, and - (1963). Blood group frequencies in mongols. ibid., $15,495$. 